\title{
RELIGIUSITAS PEDAGANG PEREMPUAN DI PASAR TRADISIONAL PROPINSI RIAU
}

\author{
Dewi Sri Suryanti, Tuti Andriani, Vera Sardila, dan Hj. Sakila \\ Fakultas Tarbiyah dan Keguruan UIN Suska Riau \\ dewisrisuryanti@uin-suska,ac,id
}

\begin{abstract}
This study was to determine the religiosity of women traders in traditional markets Riau Province. This is a qualitative descriptive study, the research subjects were women traders, while the object is religiosity women traders in traditional markets. Collecting data using interview and observation techniques, the collected data were analyzed with descriptive qualitative analysis. Religiosity in mostly women traders in traditional markets can be categorized as good (obedient) and there are still some that are categorized less good (less obedient), this can be seen in the implementation of praying the Zuhur and Asr on time or not for the Moslems, go to church or not for Christians, as well as other religions if they carry out rituals or not when they are trading, friendly or not in the buyer, honest or not in weighing goods, and others.
\end{abstract}

Kata Kunci : Religiusitas, pedagang perempuan, pasar tradisional

\section{PENDAHULUAN}

Proses pembangunan dan modernisasi yang telah terjadi di Indonesia dalam beberapa puluh tahun terakhir telah membawa banyak perubahan dalam berbagai aspek kehidupan, khususnya terhadap kaum hawa. Perubahan demikian tidak hanya terjadi pada pemikiran secara konseptual, akan tetapi juga pada aktivitas ataupun ruang gerak kaum hawa. Salah satunya adalah semakin terpinggirkannya perempuan dalam proses pembangunan. Akhir-akhir ini diskursus mengenai perempuan dalam segala sektor menjadi isu penting yang sangat santer dibicarakan, mulai dari keberadaan yang termarginalkan hingga fenomena kekerasan kehidupan serta tindakan yang diterima kaum perempuan, baik secara sadar maupun tidak sadar.

Sebagai contoh dalam sektor pertanian, modernisasi pertanian dengan teknologi canggih dan penggunaan bibit unggul di pedesaan semakin “membebaskan" para perempuan dari pekerjaan pertanian. Perempuan-perempuan ini dipaksa keluar dari bidang pertanian dan harus mencari pekerjaan diluar bidang pertanian ini. Sementara diperkotaan, keterlibatan perempuan dalam kegiatan ekonomi banyak terdapat di sektor informal terutama sektor jasa. Mereka bekerja sebagai pedagang, pembantu rumah tangga dan pelacur. Hal ini terjadi karena adanya segmentasi tenaga kerja kota. Perempuan 
terkelompokkan pada kerja-kerja yang tidak membutuhkan keterampilan. Sementara sektor industri yang bercirikan padat modal membuat kesempatan perempuan semakin kecil untuk dapat terserap dan bertahan dalam sektor ini. Penggantian tenaga kerja dengan mesin-mesin dan persaingan dengan tenaga kerja laki-laki dalam industri membuat banyak pekerja perempuan keluar dari sektor ini. Akibat tidak diterimanya perempuan dalam sektor yang lain, maka perempuan berusaha untuk masuk ke sektor lain yaitu sektor informal.

Sektor informal yang telah ada di perkotaan, dipandang sebagai solusi atas masalah ini. Pekerja perempuan yang berasal dari pedesaan maupun perkotaan dapat dengan mudah masuk ke sektor ini. Sektor informal digambarkan sebagai bagian angkatan kerja di kota yang berada di luar pasar kerja yang terorganisir. Sektor informal merupakan sektor kerja yang tidak terorganisir, memiliki fleksibilitas waktu yang tinggi, tidak mensyaratkan pendidikan khusus dan hanya membutuhkan modal yang kecil untuk memasukinya. Kekhasan sektor informal inilah yang membuat para perempuan dapat dengan leluasa memasuki sektor ini. Berada di sektor informal (publik), para perempuan ini dihadapkan pada berbagai hambatan dan faktor-faktor yang membatasi wilayah kerjanya. Pekerjaan yang mungkin untuk dimasuki oleh perempuan- perempuan ini adalah pekerjaan yang fleksibel dan memungkinkan perempuan melakukan pengasuhan dengan tetap bekerja. Pilihan usaha perempuan dalam sektor informal biasanya hanya berkisar pada beberapa komoditi atau beberapa jenis usaha saja. Seperti, pedagang sayur, pedagang ikan, usaha warung makan, pedagang kain dan semua jenis perdagangan yang dilakukan di kaki lima. Stereotipe perempuan sebagai ibu, pengasuh, lemah-lembut, teliti dan berhubungan dengan pengurus kebutuhan rumah tangga tetap membuat perempuan bekerja terkelompokkan oleh nilai budaya dan lingkungan yang membentuknya.

Secara praktis dalam paradigma modern, eksistensi perempuan dalam status dan kedudukannya secara tertentu dalam pembangunan yang berwawasan gender telah bergeser ke depan, bahkan mampu menyesuaikan diri dalam segala aspek pembangunan. Artinya, keterlibatan kaum perempuan dalam memberdayakan dirinya dan akan terus bergerak secara dinamis dengan terus berubah sesuai perkembangan. Misalnya saja aktivitas mereka dalam sektor ekonomi dapat diamati melalui keterlibatan kaum perempuan bekerja di luar rumah, seperti berdagang, bekerja lepas dan sebagainya dengan alasan pemenuhan kebutuhan ekonomi keluarga. Selain itu, tidak jarang keterlibatan perempuan dalam beraktivitas di luar rumah juga didasari atas 
keinginan dari dalam diri sendiri untuk mengembangan kemampuan secara pontensial, serta ingin menunjukkan eksistensi diri bahwa perempuan juga sama halnya dengan kaum laki-laki.

Keterlibatan perempuan dalam usaha pemenuhan ekonomi keluarga, berdasarkan pemahaman bahwa tanggung jawab untuk memenuhi ekonomi keluarga tidak saja dipandang terletak pada suami tetapi juga pada istri. Dalam konteks ini secara jelas dapat diketahui bahwa pemahaman keagamaan yang menyatakan bahwa suami bertanggungjawab untuk mencukupi kebutuhan istri tidak dapat diterima. Karena bagi mereka tugas itu harus dikerjakan secara bersama-sama, bukan siapa yang utama, tapi yang penting bagi mereka adalah kebutuhan keluarga tercukupi. Hal inilah yang menuntut perempuan melakukan aktivitas berdagang, meskipun dalam ajaran Islam tidak ada larangan untuk perempuan dalam melakukan aktifitas bekerja, salah satunya berdagang. Karena berdagang ini merupakan salah satu wujud dari aspek muamalah serta untuk mempertahankan keberlangsungan hidup.

Dalam fenomena sosial masyarakat untuk memenuhi kebutuhan ekonomi keluarga, khususnya sepertinya berdagang merupakan pilihan utama dan jalan pintas dalam memenuhi kebutuhan ekonomi keluarga, karena dirasa mudah dan tanpa memerlukan skill khusus, apalagi bagi mereka yang memiliki keterbatasan pendidikan, baik pendidikan umum maupun pendidikan agama. Keterbatasan terhadap pendidikan akan mempengaruhi pola pikir dan tindakan mereka dalam aktivitas berdagang, misalnya dalam melayani pembeli, memahami hukum-hukum berdagang menurut perspektif keagamaan dan bahkan mengatur pembinaan hubungan mereka dengan Sang Maha Pencipta.

Undang-undang No 22 tahun 1999 tentang Pemerintah Daerah dan Peraturan Pemerintah No. 25 Tahun 2000, tentang Kewenangan Pemerintah Daerah mengisyaratkan kabupaten/ kota sebagai daerah otonom. Sejak bergulirnya undangundang tersebut, mengisyaratkan bahwa kewenangan seluruh urusan pemerintahan daerah berada pada pemerintahan daerah kabupaten/ kota itu sendiri. Hal ini sekaligus memberikan tantangan tersendiri bagi daerah-daerah dalam melaksanakan pembangunan yang tentunya harus sesuai dengan kebijakan-kebijakan yang ada, mulai dari yang bersifat perencanaan, pelaksanaan hingga pengawasannya yang tidak lagi bersifat top down, tapi lebih partisipatif dengan semakin meluas dan kuatnya lembaga legislatif seperti DPRD baik secara administratif maupun praktisnya. Kondisi 
seperti inilah menjadi suatu tantangan yang akan dihadapi oleh daerah-daerah.

Pergeseran struktur sistem administrasi tersebut tidak saja merupakan momentum penting untuk memajukan daerah/ kabupaten sendiri, namun juga memberikan dampak otonomi di berbagai bidang, tanpa terkecuali pada bidang perekonomian daerah. Hal ini sesuai dengan pencapaian misi dan visi daerah Riau secara umum, terutama pada aspek ekonomi, yakni “Meningkatkan pembangunan infrastruktur ekonomi, social, politik dan budaya agar tercipta dan terlaksana pertumbuhan dan pemerataan pembangunan, pemberdayaan ekonomi rakyat, peningkatan kelembagaan masyarakat serta peningkatan pendapatan daerah".

Salah satu yang sangat dirasakan rakyat adalah masalah krisis ekonomi yang berkepanjangan dan belum teratasi. Upaya pengembangan ekonomi rakyat lebih mendorong perubahan struktur yang semula kelompok usaha yang tidak produktif, hal inilah yang pada akhirnya menjadi perhatian pemerintah. Sebagai contoh, tenaga kerja sudah tidak produktif lagi, akan tetapi pergerakan kebutuhan ekonomi terus berjalan aktif. Situasi semacam ini membuat rakyat tetap bergerak di bidang ekonomi, meskipun dengan ada modal atau tanpa modal. Hal ini merupakan salah satu langkah konkret yang dapat dilakukan untuk pemenuhan kebutuhan ekonomi secara mandiri. Dengan demikian kondisi semacam ini akhirnya mengakibatkan kaum perempuan terlibat secara produktif dalam sector ini. Bentuk keterlibatan kaum perempuan tersebut lebih terlihat nyata dalam aktivitas berdagang.

Aktivitas pedagang perempuan dapat dikategorikan dalam kerja produktif dan kerja reproduktif. Terdapat tujuh bentuk strategi yang diterapkan oleh rumah tangga pedagang perempuan yang menjadi kasus. Strategi tersebut adalah strategi spasial, strategi sektoral, strategi difersifikasi usaha dan alokasi SDM rumahtangga, strategi organisasi usaha, strategi likuidasi aset rumahtangga, strategi investasi SDM rumahtangga dan strategi mengurangi resiko usaha. Ketujuh strategi tersebut diterapkan untuk memastikan keberlangsungan usaha perdagangan dan pemenuhan nafkah rumah tangga tiap pedagang perempuan. Ketujuh strategi tersebut sangat tergantung pada kepemilikan modal dari tiap-tiap pedagang perempuan dan kemampuan mereka untuk mengakses modal tersebut. ${ }^{1}$

Dalam kaitannya dengan usaha mikro seperti berdagang, persoalan yang dihadapi adalah bagaimana mempertahankan kelangsungan hidup dari usaha yang dilakukan perhari. Ketergantungan usaha mikro yang dapat dilakukan perempuan kelas menengah ke bawah cenderung berada 
pada usaha berdagang, ini merupakan pilihan sederhana dan sekaligus ciri khas ekonomi yang melekat pada masyarakat yang memiliki tingkat keterbatasan. Di samping itu, berdagang dinilai sebagai usaha yang tidak memiliki kemampuan khusus dan mudah untuk dilakukan. Selain itu, usaha berdagang dinilai tidak merepotkan atau merugikan orang sekitarnya, asal aktivitas tersebut dilakukan sesuai ketentuann yang berlaku. Hal ini juga berkaitan dengan anjuran bagi orang-orang muslim untuk berjuang mencari nafkah yang halal sepanjang hidup mereka dan semata-mata tidak bergantung kepada orang lain/ dermawan ataupun meminta-minta, kecuali dalam keterpaksaan. Sebagaimana Rasululah SAW bersabda dalam hadits Sunan AnNasa'I bahwa tangan di atas lebih baik daripada tangan di bawah, tangan yang di atas ialah orang yang bersedekah dan tangan yang di bawah ialah orang yang meminta.

Sebagaimana juga Firman Allah SWT dalam surat Al-Baqarah ayat 275 (QS:2:275) :

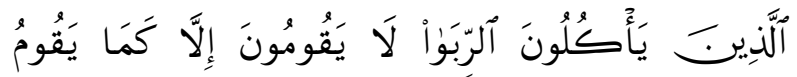

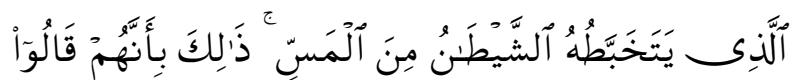

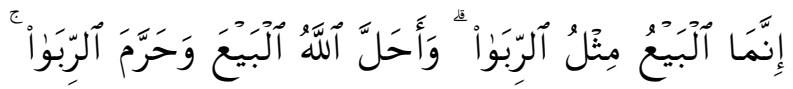

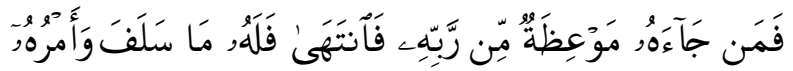

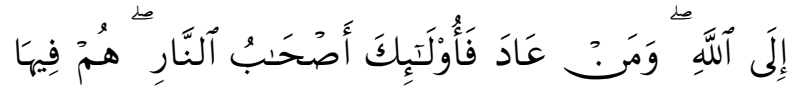

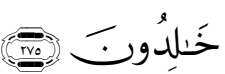

Artinya : Orang-orang yang makan (mengambil) riba tidak dapat berdiri melainkan seperti berdirinya orang yang kemasukan syaitan lantaran (tekanan) penyakit gila. keadaan mereka yang demikian itu, adalah disebabkan mereka Berkata (berpendapat), Sesungguhnya jual beli itu sama dengan riba, padahal Allah Telah menghalalkan jual beli dan mengharamkan riba. orang-orang yang Telah sampai kepadanya larangan dari Tuhannya, lalu terus berhenti (dari mengambil riba), Maka baginya apa yang Telah diambilnya dahulu (sebelum datang larangan); dan urusannya (terserah) kepada Allah. orang yang kembali (mengambil riba), Maka orang itu adalah penghunipenghuni neraka; mereka kekal di dalamnya.

Dan surat An-Nisa ayat 29 (QS.4: 29) :

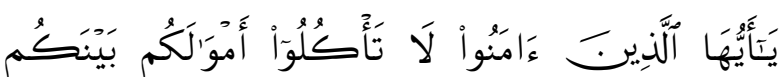

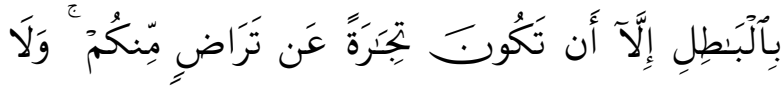

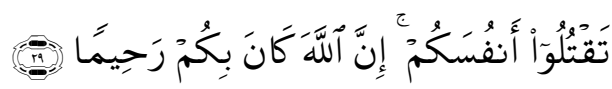
Artinya : Hai orang-orang yang beriman, janganlah kamu saling memakan harta sesamamu dengan jalan yang batil, kecuali dengan jalan perniagaan yang berlaku dengan suka sama-suka di antara kamu. dan janganlah kamu membunuh dirimu; Sesungguhnya Allah adalah Maha Penyayang kepadamu.

Secara garis besar, hal diatas menjelaskan bahwa jual-beli atau perniagaan 
dapat dimaknai dengan perdagangan yang merupakan usaha dalam memenuhi kebutuhan, tentunya kriteria perdagangan ditekankan pada prinsip-prinsip Islam. Seiring dengan penjelasan di atas, sejumlah petunjuk Al-Qur'an dan Hadis Nabi Muhammad SAW mendorong manusia, terutama umat Islam untuk terlibat aktif dalam perdagangan dan tidak dibenarkan menyimpang dari peraturan-peraturan yang baik dalam hukum Islam serta tanpa melupakan kewajiban (pengabdian kepadaNya). Misalnya perintah menyegerakan panggilan adzan untuk melaksanakan sholat dengan menghentikan kegiatan perdagangan.

Secara normatif, Al-Qur'an telah menawarkan etika dagang dalam prinsip keadilan serta kejujuran. Sistem etika perdagangan pada dasarnya ditetapkan guna menghindari kecurangan dan mengatur perilaku-perilaku yang terkait dalam sistem perdagangan. Selanjutnya, dalam pandangan Islam kejujuran dan kebenaran adalah suatu hal yang sangat fundamental yang harus ditanamkan dalam diri setiap individu. Di samping itu, dalam pandangan Islam dari segi muamalah, etika berdagang didasarkan pada pola tingkah laku demi tercapai tujuan bagi kehidupan manusia.

Menurut Al-Qur'an dan Sunnah Nabi, dirumuskanlah prinsip-prinsip yang digunakan dalam bisnis niaga yakni :
Kejujuran, Keramahtamahan, Penawaran yang jujur, Pelanggan yang tidak sanggup membayar diberi waktu, Tidak memaksa pembeli, Tegas dan adil dalam timbangan / takaran, Tidak memonopoli, dan Kesukarelaan. Dari berbagai prinsip ini dapat disimpulkan bahwa transaksi jual beli terlaksana dengan baik karena didasari oleh etika yang sekaligus dijadikan sebagai pegangan dalam setiap tindakan.

Kemudian, pada saat memenuhi kebutuhan dan pengeluaran rumah tangga dalam sektor ekonomi pada umumnya, posisi perempuan bergerak pada komersial industri mikro, di mana usaha dalam pengumpulan modal hanya digunakan untuk pemenuhan kebutuhan keluarga sehari-hari. Ciri perempuan di sektor informal pada umumnya yakni berpendidikan rendah dan berada pada usia produktif, biasanya mereka bekerja dengan alasan "survive" secara ekonomi.

Agaknya karakteristik marjinal dan substansi ekonomi yang dijalankan perempuan dalam sektor perdagangan sangat lekat dengan fenomena masyarakat di tingkat taraf kesejahteraan hidup menengah ke bawah, hal ini karena keterbatasan ilmu, pendidikan, akses informasi dan lapangan kerja. Maka perempuan dalam kelompok ini harus bertahan hidup dengan mengembangkan pola-pola usaha ekonomi 
sosial yang terbatas, terutama dalam mengatasi masa krisis.

Dalam menghadapi masa krisis, pedagang perempuan menerapkan strategi bertahan dan tidak melakukan perlawanan. Likuidasi aset rumah tangga menjadi solusi untuk mengatasi masa krisis. Pedagang perempuan menjual barang-barang yang dimilikinya untuk tambahan usaha maupun untuk memenuhi kebutuhan konsumsi anggota rumah tangganya. Saat tahap pemulihan krisis, prioritas utama pedagang perempuan adalah membeli kios sebagai jaminan terhadap kepastian usaha. Dapat disimpulkan bahwa, meskipun pedagang perempuan memiliki keragaman dalam karakteristik individu maupun rumah tangga, mereka menerapkan strategi menghindari konflik dan pedagang perempuan memiliki kemampuan yang besar dalam bertahan terhadap musibah atau krisis yang menimpa usahanya. ${ }^{2}$

Faktor penyebab perempuan memasuki sektor informal, seperti usaha perdagangan adalah; a) ketidaksempurnaan pasar yang disebabkan oleh ketatnya persyaratan yang ditentukan untuk dapat memasuki sektor formal, seperti pendidikan dan ketrampilan yang memadai, b) paradigma industrialisasi dalam pembangunan yang memicu pertumbuhan penduduk dan angka kemiskinan di desa tinggi dan pendapatan di kota yang lebih tinggi dari pada di desa, c) kondisi alam yang tandus, krisis air, dan berbukit-bukit. Sementara itu, kontribusi pendapatan perempuan pedagang pasar dalam rumah tangga meliputi: pemenuhan kebutuhan sehari-hari, biaya pendidikan dan untuk membeli rumah atau membuat rumah. Sedangkan sektor informal perdagangan mempunyai keterkaitan yang erat dengan sektor formal dalam menyuplai bahan baku dan layanan jasa bagi tenaga kerja sektor formal. Namun, mereka sulit mendapatkan fasilitas kredit, perlindungan, perserikatan dan pelatihan dan pembinaan. Oleh karena itu, pemerintah diharapkan intervensinya dalam pengembangan usaha perdagangan mereka. ${ }^{3}$

Carl Jung, seorang sosiolog menjelaskan bahwa pada dasarnya dalam diri manusia secara utuh, baik perempuan maupun laki-laki, terdapat dua prinsip/ aspek, yaitu "logos dan eros". Aspek ini sekaligus merupakan kualitas kemanusiaan yang bersifat universal. Dalam hal ini beliau memberi batasan mengenai kedua aspek susunan keteraturan serta pengembangan potensi. Sedangkan eros merupakan prinsip feminim dalam kepribadian yang berorientasi pada moral (memelihara hubungan interpersonal dengan cara mengasuh, memberi cinta kasih, afektif, 
kepekaan, serta emosi, sosialibilitas). Logos dimaknai sebagai prinsip maskulin, berorientasi pada pencapaian prestasi dan potensi dengan ciri-ciri rasio berpikir, logika, memberi bentuk, lebih pahami keadaan lakilaki dan sebaliknya.

Berbicara mengenai potensi perempuan, maka harus didasarkan pada pengetahuan tentang kondisi mereka, termasuk analisis tentang ketertinggalan mereka dalam pembangunan dibanding dengan laki-laki, sebagai suatu contoh di bidang pendidikan. Di bidang pendidikan, kuantitas dan kualitas perempuan masih relatif tertinggal dibanding laki-laki. Peluang ini tereduksi dengan konstruksi budaya yang menyatakan perempuan tidak perlu sekolah tinggi karena posisi perempuan nantinya akan selalu berada di rumah tangga.

Dalam Ensiklopedi Islam diuraikan bahwa perempuan diibaratkan sebagai tiang negara, apabila ia baik maka negara akan baik dan jika rusak maka negara akan rusak. Islam tidak membuat diskriminasi antara perempuan dan laki-laki. Keduanya dipandang sama, yaitu sama-sama hamba Allah SWT. Siapa saja hamba Allah SWT, baik laki-laki atau perempuan, jika ia beriman dan beramal shaleh akan mendapat pahala sesuai dengan iman dan amalnya. Sebaliknya jika ia kafir, maka ia akan mendapat balasan yang setimpal. ${ }^{4}$
Penelitian di bidang gender, para pemikir konservatif menafsirkan reformasi yang jelas, yang dilakukan Al-Qur'an terhadap praktek historis dan kultur sebagai pernyataan yang sesungguhnya dan pasti tentang praktek tersebut untuk selamanya dan dimanapun. Yang dibutuhkan adalah suatu pemahaman yang menganggap perubahan tersebut sebagai upaya membangun preseden untuk dikembangkan secara berkelanjutan menuju sebuah tatanan sosial yang adil. Tatanan sosial yang adil dan komprehensif tidak saja memperlakukan perempuan secara adil, tetapi juga melibatkan perempuan sebagai agen yang bertanggung jawab untuk memberikan konstribusi terhadap semua persoalan yang berhubungan dengan masyarakat.

Ajaran Islam yang dikembangkan oleh nabi Muhammad SAW mengakui hak usaha dan profesi kaum perempuan, serupa dengan hak usaha dan profesi untuk kaum laki-laki, sebagaimana yang dinyatakan dalam Al-Qur'an surat An-Nisa' ayat 32 (QS.4:32) :

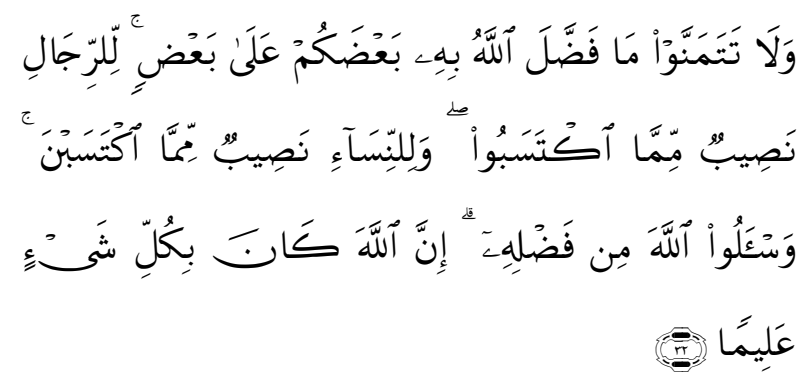

Artinya : Dan janganlah kamu iri hati terhadap apa yang dikaruniakan Allah 
kepada sebahagian kamu lebih banyak dari sebahagian yang lain. (karena) bagi orang laki-laki ada bahagian dari pada apa yang mereka usahakan, dan bagi para perempuan(pun) ada bahagian dari apa yang mereka usahakan, dan mohonlah kepada Allah sebagian dari karunia-Nya. Sesungguhnya Allah Maha mengetahui segala sesuatu.

Sementara itu, wacana yang berkembang dalam masyarakat, masih terjadi dua kutub berseberangan. Pada satu sisi menyatakan bahwa perempuan harus beraktifitas di dalam rumah, di sisi lain membolehkan perempuan untuk beraktifitas di luar rumah. Sedangkan dalam pandangan Islam tidak membedakan kaum laki-laki dengan perempuan dalam hak-hak individu. Namun hal demikian perlu diperhatikan dalam batasan-batasan kodrat sebagai perempuan.

Berdasarkan observasi awal di beberapa pasar tradisonal provinsi Riau aktivitas berdagang yang dilakukan oleh perempuan berjalan dengan baik, akan tetapi masih terdapat juga beberapa pedagang perempuan yang masih mengenyampingkan nilai-nilai keagamaan, seperti adanya ketidakjujuran dalam timbangan, melalaikan dan meninggalkan aktifitas yang berkaitan dengan ibadah, seperti shalat, dll.

\section{METODE PENELITIAN}

Penelitian ini dilaksanakan di beberapa pasar tradisional di empat kabupaten/kota di Provinsi Riau, yaitu Kota Pekanbaru, Kabupaten Pelalawan, Kota Dumai dan Kabupaten Kampar. Dan waktu penelitian pada bulan Agustus sampai dengan Desember 2010

Sesuai dengan tujuan yang hendak dicapai, maka metode penelitian yang digunakan pada penelitian ini adalah metode deskriptif kualitatif yang tujuannya untuk mendeskripsikan atau memberikan gambaran, informasi terhadap hal-hal yang diamati sesuai dengan yang diteliti. Metode kualitatif digunakan untuk mendapatkan data yang mendalam terhadap kasus yang akan diteliti. Jadi secara umum, penelitian ini menggambarkan dan menganalisis serta mengamati segala sesuatu yang ada dan terjadi di lapangan.

Penentuan informan dengan menggunakan teknik sampling non-random yaitu dengan sampling bertujuan (purposive sampling) dengan mengembangkan sample yang dipandang layak dijadikan sumber informasi. ${ }^{5}$ Apabila data yang dicari sudah dipandang layak dan cukup maka penggalian data dihentikan. Dengan demikian, informan dalam penelitian adalah pedagang perempuan di pasar tradisional 
Provinsi Riau. Hal demikian sekaligus merupakan subjek dari penelitian ini. Sedangkan objeknya adalah religiusitas pedagang perempuan di pasar tradisional Provinsi Riau. Selanjutnya, penelitian ini juga diperkuat oleh data-data dari pengelola pasar, penjaga keamanan (sekuriti) dan masyarakat di sekitar pasar tradisional tersebut.

Adapun teknik pengumpulan data, dengan menggunakan :

\section{Wawancara}

Teknik wawancara yang digunakan dalam penelitian kualitatif ini adalah wawancara mendalam. Wawancara mendalam (indepth interview) adalah proses memperoleh keterangan untuk tujuan penelitian dengan cara tanya jawab sambil bertatap muka antara pewawancara dengan informan atau orang yang diwawancarai, dengan atau tanpa menggunakan pedoman (guide) wawancara.

Wawancara ini dilakukan dengan membuat pedoman wawancara mengenai aspek-aspek yang diamati dan relevan dengan yang akan dianalisis.

Pada penelitian yang berbentuk studi kasus, lazimnya dituntut suatu wawancara mendalam (indepth interview), dituntut banyak pelacakan (probing) guna mendapatkan data yang lebih dalam, utuh dan rinci. Oleh karena itu pedoman wawancara pada studi kasus, lazimnya hanya memuat "pertanyaan-pertanyaan pokok", yang umumnya berbentuk pertanyaan terbuka atau tak terstruktur adalah tugas pewancara untuk melacak secara lebih jauh, mendalam, lengkap dan rinci. Di sini kemampuan, kecerdikan dan kejelian pewawancara untuk melacak menjdi persyaratan utama. Oleh karena itu wawancara dalam studi kasus dilakukan oleh peneliti itu sendiri. ${ }^{6}$

\section{Observasi}

Beberapa informasi yang diperoleh dari hasil observasi adalah ruang (tempat), pelaku, kegiatan, objek, perbuatan, kejadian atau peristiwa, waktu dan perasaan. Alasan peneliti melakukan obsevasi adalah untuk menyajikan gambaran realistik perilaku atau kejadian, untuk menjawab pertanyaan, untuk membantu mengerti perilaku manusia dan untuk evaluasi yaitu melakukan pengukuran terhadap aspek tertentu dan melakukan umpan balik terhadap pengukuran tersebut. Dengan mengamati pelaku melalui observasi tersebut, maka akan diketahui dan diperoleh gambaran dan data mengenai pedagang perempuan dalam menjalankan aktivitasnya sesuai dengan yang diharapkan pada penelitian tersebut.

Untuk analisis data digunakan analisis deskriptif kualitatif. Analisis deskriptif dengan pendekatan kualitatif ini, pada 
dasarnya bertujuan untuk memahami keberadaan yang saling berhubungan antara berbagai gejala eksternal maupun internal yang terdapat dalam kehidupan pedagang perempuan di pasar tradisional. Penelitian deskriptif menggambarkan dengan tepat mengenai sifat-sifat individu, keadaan, gejala dan kelompok tertentu, menentukan frekuensi adanya hubungan tertentu antara satu gejala dengan gejala lainnya dalam masyarakat. Metode penelitian kualitatif merujuk kepada prosedur penelitian yang menghasilkan data deskriptif, yakni apa yang dituturkan orang, baik lisan maupun tulisan, apa yang dilakukan orang, yang secara fundamental bergantung pada pengamatan manusia dalam keluasannya sendiri dan berhubungan dengan orang tersebut dalam bahasanya serta dalam peristilahannya. ${ }^{7}$

Langkah-langkah analisis data pada penelitian ini yaitu :

a. Mengorganisir informasi

b. Membaca keseluruhan informasi dan memberi kode

c. Membuat suatu uraian terperinci mengenai kasus dan konteksnya

d. Peneliti menetapkan pola dan mencari hubungan antara beberapa kategori.

e. Selanjutnya peneliti melakukan interpretasi dan mengembangkan generalisasi natural dari kasus baik untuk peneliti maupun untuk penerapannya pada kasus yang lain.

f. Menyajikan secara naratif

\section{PEMBAHASAN}

1. Temuan Data

a. Pedagang Perempuan Di Pasar

Tradisional Kota Pekanbaru

Pasar yang diamati adalah Pasar Cik

Puan. Pasar ini semulanya berasal dari pasar inpres berdiri pada tahun 1978 dan dibangun atas dasar prakarsa swadaya para pedagang sehingga menjadi pasar tradisional. Sedangkan ditinjau dari segi letak geogafis, Pasar Cik Puan berada dalam wilayah Jadirejo Kecamatan Sukajadi. Posisi sebelah barat berbatasan dengan Jalan Utama; sebelah timur berbatasan dengan Panti Asuhan Putra Muhammadiyah; sebelah selatan berbatasan dengan Jalan Nangka/Tuanku Tambusai; dan sebelah utara berbatasan dengan Jalan Kusuma.

Salah seorang responden RB (inisial), berusia 40 tahun, bersuku Melayu, merupakan salah seorang pedagang perempuan yang sudah berdagang lebih dari 10 tahun di pasar tradisional kota Pekanbaru, mengatakan bahwa hampir setiap hari kegiatan dan aktivitas di pasar berjalan sebagaimana biasanya. Aktivitas dagang ini dilakukan oleh para perempuan dengan tingkat usia yang beragam (berusia sekitar 
20-an hingga 60-an) dan juga masa berdagang yang beragam (ada yang baru hitungan bulan dan ada juga yang sudah berdagang puluhan tahun). Data tersebut dapat dilihat pada tabel di bawah ini:

TABEL. 1

Persentase Rentang Usia Pedagang Perempuan Kota Pekanbaru

\begin{tabular}{clc}
\hline NO & RENTANG USIA & PERSENTASE \\
\hline 1 & $20-30$ tahun & $\mathbf{1 5 \%}$ \\
2 & $31-40$ tahun & $\mathbf{2 5 \%}$ \\
3 & $41-50$ tahun & $\mathbf{5 0 \%}$ \\
4 & $51-$ ke atas & $\mathbf{1 0} \%$ \\
\hline
\end{tabular}

Tabel di atas memberikan penjelasan kepada kita bahwa pedagang perempuan yang berdagang di Kota Pekanbaru rata-rata berada pada tingkat usia yang dimulai dari 20 tahun sampai 50 ke atas. Apabila dilihat dari persentase yang tertinggi, maka para pedagang perempuan tersebut rata-rata berada pada rentang usia 41 - 50 tahun.

Selanjutnya beliau menyebutkan bahwa tidak semua pedagang di Pasar Cik Puan memiliki kios, sehingga mereka yang tidak memiliki kios terkadang kegiatan berdagang dilakukan dengan berpindah-pindah tempat di seputaran pasar tersebut. Alasan tidak memiliki kios cukup beragam, diantaranya : keterbatasan modal, rumitnya mendapatkan kios-kios untuk menjadi milik sendiri, musibah kebakaran pasar yang telah terjadi beberapa kali, adanya rencana pemerintah untuk merenovasi Pasar Cik Puan menjadi pasar modern, dll.

Berdasarkan hasil pengamatan, jenis dagangan sangat beragam, hampir keseluruhan sayur mayur dan lauk pauk diperdagangkan di pasar tsb. Ada keunikan yang tampak di pasar, yaitu barang yang dijual dipengaruhi juga oleh kultur yang dominan. Misalnya pedagang perempuan bersuku Batak lebih dominan menjual sayurmayur, seperti bayam, kangkung, daun singkong dan lainnya. Sedangkan pedagang perempuan bersuku Minang lebih cenderung menjual ikan, ayam, sayur mayur bahkan ada juga yang menjual bahan sembako. Kemudian pedagang perempuan Etnis Tionghoa, biasanya lebih dominan menjual bahan-bahan kue dan sembako.

Pasar pada pagi hari sangatlah ramai dengan lalu-lalang pembeli, suara-suara pedagang terdengar saling bersahutan memanggil para pembeli dan menawarkan dagangannya. Komunikasi mereka cenderung menggunakan Bahasa Minang, hal ini dikarenakan dominannya pedagang perempuan berasal dari Sumatera Barat, walaupun pada kenyataannya ada juga para 
pedagang perempuan tersebut berasal dari Suku Batak, Suku Melayu, etnis Tionghoa, dll. Tapi mereka lebih suka dan fasih berbahasa Minang dalam berkomunikasi, hal ini kemungkinan disebabkan pengaruh dominannya masyarakat Minang tersebut.

Sebagaimana telah dipaparkan sebelumnya, bahwa masyarakat di Kota Pekanbaru menganut berbagai agama, salah satu agama yang cukup dominan adalah agama Islam. Berdasarkan hasil pengamatan, ternyata jumlah pedagang perempuan yang beragama Islam juga lebih banyak dari agama lainnya. Data ini memberikan gambaran kepada kita bahwa hampir lebih sebagian pedagang perempuan di Kota Pekanbaru beragama Islam. Keberadaan pedagang perempuan yang beragama Islam jelas disebabkan karena pada umumnya mereka mayoritas bersuku Melayu dan Minang, karena sejauh ini Suku Melayu dan Minang itu identik dengan keislamannya.

Sedangkan yang beragama Kristen, umumnya bersuku Batak yang berasal dari Propinsi Sumatera Utara. Selanjutnya keberadaan agama Hindu dan Budha disebabkan karena; pertama adanya masyarakat Tionghoa yang memang pada dasarnya mereka sengaja datang untuk berdagang yang merupakan warisan leluhur yang turun temurun. Kedua, adanya perkawinan dengan penduduk setempat.

Dalam hal religi, pedagang perempuan yang beragama Islam ditemukan sebagian dari mereka melaksanakan ibadah shalat tepat waktu dan di awal waktu, sebagian yang lain ada yang tergantung dengan kondisi ramai atau tidaknya pembeli, kalau sepi baru melaksanakan shalat, ada juga yang tidak melaksanakan shalat dengan alasan yang beragam. Pengamatan ini dilakukan pada saat waktu Shalat Zuhur dan Ashar, dikarenakan pelaksanaan shalat ini bertepatan dengan aktivitas berdagang mereka yang dimulai dari pukul 06.00 WIB hingga pukul 18.00 WIB. Untuk pelaksanaan Shalat Zuhur dan Ashar terkadang mereka melakukannya di masjid, mushalla yang berada di sekitar pasar dan kios-kios tempat mereka berjualan.

Adapun dalam aktivitas jual-beli, terutama pada aspek pelayanan pembeli, mereka melayani sesuai dengan syariah agama, misalnya dalam hal keramahan melayani pelanggan, tergambar dari cara melayani pembeli dengan sapaan yang baik, senyum yang tulus dan diselingi dengan gurauan yang menarik sehingga terjalin rasa kekeluargaan.

Kemudian, dalam aspek penimbangan, para pedagang melakukan penimbangan di hadapan pembeli secara transparan, sehingga menimbulkan rasa puas pembeli dan diharapkan pembeli tersebut di lain hari akan kembali lagi untuk berbelanja. Di satu sisi ketransparanan ini sangat bagus dilaksanakan, tapi di sisi lain juga patut dipertanyakan standar alat timbang yang digunakan karena ada beberapa kejadian 
barang yang sudah dibeli tidak sesuai dengan timbangan yang seharusnya.

Dalam hal penetapan harga, mereka menyesuaikan dengan kondisi harga di pasaran, dengan tidak mengambil keuntungan yang terlalu tinggi. Masalah harga bagi mereka merupakan faktor penentu dari nilai jual-beli barang setiap harinya, oleh sebab itu, mereka lebih realistis terhadap harga-harga di pasaran. Hal ini mereka lakukan dengan prinsip supaya jualan mereka bisa habis dan dapat ditambah dan bertukar kembali setiap harinya.

Untuk pedagang perempuan yang beragama Kristen, dalam pelaksanaan ibadah khususnya pada hari Minggu pagi, hanya sebagian yang pergi ke gereja dan sebagian yang lain tidak pergi dengan beragam alasan, diantaranya karena lebih mengutamakan berdagang. Hal ini mereka lakukan karena kondisi pasar pada hari minggu itu lebih ramai karena pada hari Minggu merupakan hari libur kerja dan pasar justru sangat ramai dikunjungi masyarakat.

Dilihat dari aspek pelayanan pelanggan, mereka melayani dengan baik dan sedikit tegas, hal ini disebabkan karena kultur budaya mereka (mayoritas dari Sumatera Utara) dalam berkomunikasi cenderung dengan logat yang khas. Sedangkan pada aspek penimbangan, para pedagang juga melakukan timbangan di hadapan pembeli secara transparan, seperti halnya yang dilakukan oleh pedagang perempuan yang beragama Islam. Masalah standarisasi alat timbang juga patut dipertanyakan, sebagian menimbang dengan alat timbang yang baik dan sebagian yang lain menggunakan alat timbang yang tidak baik (misal, alat timbang yang sudah tidak patut digunakan maupun alat timbang yang sudah di rekayasa oleh si penjual).

Untuk yang beragama Hindu, Budha, dan Konghucu yang mayoritas dianut oleh Etnis Tionghoa, sebelum aktivitas dagang dilakukan mayoritas mereka terlebih dahulu melakukan persembahyangan sesuai dengan tata cara peribadatan agama mereka.

Dalam hal penimbangan barang Etnis Tionghoa bersikap jujur, kemudian dalam penetapan harga jarang terjadi tawarmenawar, karena mereka sudah menetapkan harga yang pas sesuai harga pasaran. Prinsip pedagang Tionghoa, mereka tidak perlu mengambil untung sebesar-besarnya yang penting perputaran barang berjalan dengan cepat.

b. Pedagang Perempuan Di Kabupaten Kampar

Kabupaten Kampar memiliki banyak pasar, mulai dari pasar tradisional yang bersifat permanen hingga pasar-pasar yang bersifat mingguan yang dibuka pada harihari tertentu. Salah satu pasar yang diamati adalah Pasar Kampar yang berada di Kecamatan Kampar Timur, Kabupaten Kampar tepatnya berada di Jalan raya Pekanbaru-Bangkinang KM 30. 
Pasar Kampar ini tidak begitu luas hal ini disebabkan karena posisinya tepat di pinggir jalan raya Pekanbaru-Bangkinang dan sebelah kiri berbatasan dengan jalan kecil dan bagian belakang berbatasan dengan rumah penduduk, sebelah kanan berbatasan dengan masjid besar yang bernama Masjid Nurul Iman. Masjid ini berdiri megah dengan asitektur gedung yang indah dan tingkat kebersihan juga cukup standar (lumayan bersih), hal ini terlihat dari kenyamanan pengunjung dalam melaksanakan ibadah shalat, begitu juga dengan tempat berwudhuknya yang cukup bersih.

Pada saat pengambilan data, kondisi pasar ini sedang perbaikan( renovasi), karena pada tahun 2006 pasar Kampar mengalami kebakaran yang hebat. Peristiwa kebakaran ini menghabiskan sejumlah toko dan kios yang berada di depan pasar.

Sebagaimana telah dijelaskan bahwa pasar Kampar ini merupakan pasar mingguan dimana masyarakat berkumpul dalam aktivitas jual beli sehingga jika dilihat dari jumlah pedagang diperkirakan sekitar 300-400 orang. Pedagang-pedagang tersebut banyak didominasi oleh kaum perempuan yang rata-rata berusia 40 tahun ke atas. Data tersebut dapat dilihat pada tabel di bawah ini:

\section{TABEL 2}

Persentase Rentang Usia Pedagang Perempuan Kabupaten Kampar

\begin{tabular}{ccc}
\hline NO & \multicolumn{1}{c}{ RENTANG USIA } & PERSENTASE \\
\hline 1 & $20-30$ tahun & $\mathbf{1 0} \%$ \\
2 & $31-40$ tahun & $\mathbf{1 5 \%}$ \\
3 & $41-50$ tahun & $\mathbf{4 0} \%$ \\
4 & $51-$ ke atas & $\mathbf{3 5 \%}$ \\
\hline
\end{tabular}

Tabel di atas menggambarkan bahwa persentase tingkat usia pedagang perempuan yang ada di Kabupaten Kampar menunjukkan banyak pada rentang usia 50 tahun ke atas. Dapat disimpulkan bahwa perempuan yang berdagang di wilayah Kampar kebanyakan perempuan yang sudah berusia lanjut walaupun masih terdapat juga yang muda dengan persentase yang kecil.

Berdasarkan data yang diperoleh melalui responden NR (inisial) berusia 40 tahun ini mengatakan bahwa aktivitas ini dilakukannya mulai dari setelah subuh sekitar pukul 06.00WIB hingga sampai waktu Ashar sekitar pukul 15.00-16.00 WIB, demikian juga dengan pedagang lainnya. Responden juga menambahkan bahwa kegiatan berdagang dilakukan di toko sendiri, walaupun bersifat sederhana dan tidak begitu luas. Selain itu, masih banyak juga para pedagang perempuan lainnya yang berdagang secara berpindah-pindah tempat. Hal ini disebabkan karena belum memiliki lapak atau kios secara pribadi. Di samping 
itu juga, berdagang dengan berpindahpindah dilakukan karena pasar yang bersifat mingguan.

Sama halnya dengan pilihan jenis dagangan yang ada di Kota Pekanbaru, maka jika dilihat dari jenis dagangan yang diperjualbelikan di pasar ini, responden mengatakan bahwa jenis dagangan yang banyak dijual berupa sayur mayur, ikan, beras, selain itu tedapat pula beberapa pedagang yang menjual pakaian. Pilihan mereka dalam menjual jenis pakaian dengan alasan pasar bersifat mingguan sehingga banyak pengunjung yang membeli pakaianpakaian yang di bawa dari kota besar.

Sama halnya juga dengan Kota Pekanbaru, maka jenis dagangan yang diperjualbelikan dipengaruhi oleh kultur yang dominan, misal pedagang perempuan bersuku Batak lebih dominan menjual sayur mayur, pedagang perempuan bersuku Minang lebih cenderung menjual ikan, ayam, cabe dan sembako, sedangkan pedagang perempuan Etnis Tionghoa lebih dominan menjual bahan-bahan kue dan sembako.

Sebagaimana telah dipaparkan sebelumnya, bahwa masyarakat di Kabupaten Kampar menganut berbagai agama, salah satu agama yang cukup dominan adalah agama Islam. Berdasarkan hasil pengamatan, ternyata jumlah pedagang perempuan yang beragama Islam juga lebih banyak dari agama lainnya. Data ini memberikan gambaran kepada kita bahwa hampir lebih sebagian pedagang perempuan di Kabupaten Kampar beragama Islam. Keberadaan pedagang perempuan yang beragama Islam jelas disebabkan karena pada umumnya mereka mayoritas bersuku Melayu dan Minang, karena sejauh ini suku Melayu dan Minang itu identik dengan keislamannya.

Ketaatan Responden sebagai muslimah dalam melaksanakan ibadah keagamaan terlihat saat memasuki waktu zuhur dan ashar dengan melaksanakan ibadah shalat. Pada umumnya pedagang perempuan di pasar ini melaksanakan shalat sesuai pada waktunya. Sedangkan untuk aktivitas berdagang sudah dimulai dari pukul 06.00 WIB hingga pukul 18.00 WIB. Sementara responden sendiri mulai melakukan aktivitas dagang pukul 07.00 WIB, dengan demikian Shalat Subuh pastinya sudah dilakukan di rumah. Sedangkan ibadah shalat zhuhur, terkadang dilakukan di mesjid yang tepat berada di samping pasar. itu pun jika ada yang menggantikan untuk menjaga kiosnya. Kalau tidak ada yang menggantikan, terkadang dia menitipkan sementara lapak/kios ke pedagang di sebelah lapak/kiosnya untuk mengambil wudhu, setelah selesai berwudhu dia kembali ke lapak/kios dan melaksanakan shalat Zuhur di sela-sela kain dagangannya, demikian juga dengan shalat Ashar.

Untuk pedagang perempuan yang beragama Kristen, dalam pelaksanaan ibadah khususnya pada hari Minggu pagi, hanya sebagian yang pergi ke gereja dan sebagian 
yang lain tidak pergi dengan beragam alasan, salah satu alasannya adalah mengutamakan berdagang karena pasar pada hari minggu itu lebih ramai dikunjungi masyarakat sekitar.

Sementara itu dalam aktivitas jual-beli, terutama pada aspek pelayanan pembeli, mereka melayani dengan baik dan ramah, menyapa dengan sapaan yang baik, senyum yang tulus dan diselingi dengan gurauan yang menarik sehingga terjalin rasa kekeluargaan.

Kemudian, dalam aspek penimbangan para pedagang melakukan penimbangan barang di hadapan pembeli secara transparan, hal ini bisa mendatangkan kepuasan baik oleh si penjual maupun si pembeli bahwa barang yang diperjualbelikan sesuai dengan kesepakatan berdua. Hanya sangat disayangkan, sebagian kecil pedagang ada yang menggunakan alat timbang yang tidak sesuai lagi timbangannya.

Dalam hal penetapan harga, mereka menyesuaikan dengan kondisi harga di pasaran, dengan tidak mengambil keuntungan yang menyolok. Masalah harga bagi mereka merupakan faktor penentu dari nilai jual-beli barang setiap harinya, oleh sebab itu, mereka lebih realistis terhadap harga-harga di pasaran. Hal ini mereka lakukan dengan prinsip supaya jualan mereka bisa habis dan dapat ditambah dan bertukar kembali setiap harinya. Misalnya, responden dalam berjualan menggunakan cara tawar-menawar (bukan harga pas), harga akhir adalah hasil kesepakatan bersama antara responden dan si pembeli, kalau si-pembeli meminta harga dibawah harga modal maka responden dengan jujur mengatakan berapa modal yang sebenarnya dan meminta kepada pembeli untuk menaikkan harga di atas modal setelah itu terserah kepada pembeli akan memberikan keuntungan berapa kepada responden. Cara seperti ini merupakan kekhasan dalam berdagang di daerah Kampar yang hampir mayoritas adalah pemeluk agama Islam. Melalui aktivitas berdagang inilah hampir di setiap keluarga yang berprofesi pedagang sudah mampu melaksanakan ibadah haji dan panggilan Pak Haji atau Buk Haji/ Hajjah agaknya sudah menjadi hal yang lumrah dan juga menjadi kebanggaaan. Karena kebanggaan sudah pernah ke tanah suci inil juga yang menjadi faktor pendorong para generasi muda untuk berlomba-lomba secepatnya ke tanah suci. Dan cara tercepat untuk mengumpulkan uang untuk perjalanan haji ini adalah dengan berdagang, sehingga roda perekonomian di daerah berjalan dengan pesat dan pasar Kampar menjadi pasar kedua terbesar di Kabupaten Kampar setelah pasar Bangkinang (Ibukota Kabupaten Kampar adalah Bangkinang, dengan julukan kota beriman).

Demikian juga halnya dengan responden kedua, yakni IM (inisial) yang berumur umur 69 tahun. Responden sudah berdagang cendol lebih kurang 20 tahun. Harga satu mangkok Rp. 4.000,- dan ini 
harga yang standar di daerah kampar tersebut. Interaksi responden dengan pedagang lainnya sangat baik dan tatkala azan Zuhur berkumandang, dia akan bergantian dengan suami maupun anaknya dalam melaksanakan shalat di masjid Nurul Iman tersebut.

Selanjutnya, salah seorang tenaga keamanan di pasar tersebut menambahkan bahwa pelaksanaan ibadah shalat para pedagang di pasar kampar ini termasuk baik, hanya yang menjadi kendala tidak selalu tepat waktu disebabkan harus menunggu para pengganti yang akan menjaga kios/lapak mereka terlebih dahulu. Sedangkan dalam interaksi sosial sesama pedagang sangat bagus (lebih pada sifat kekeluargaan) tidak seperti di kota-kota besar yang lebih cenderung individualistis. Menurut responden di pasar ini tidak ada satpam khusus, yang ada nampak setiap hari pasar tersebut hanyalah polisi yang mengatur lalu lintas di depan pasar (karena pasar berada di sebelah kanan dan kiri jalan raya Bangkinan-Pekanbaru). Responden juga mengatakan hampir $100 \%$ pedagang di pasar Kampar tersebut beragama Islam.

c. Pedagang Perempuan Di Kabupaten Pelalawan

Berdasarkan hasil pengamatan dan wawancara dari responden bernama RK (inisial) yang berusia 50 tahun. Beliau sudah menjalankan aktivitas berdagang di pasar tradisional Pelalawan ini sejak tahun 2001. Berdasarkan keterangannya, rata-rata kaum perempuan yang berjualan di sekitar pasar ini cenderung sudah berusia lanjut (40 tahun ke atas). Distribusi rentang usia pedaang perempuan di wilayah tersebut dapat digambarkan melalui tabel di bawah ini.

TABEL 3

Persentase Rentang Usia Pedagang Perempuan Kabupaten Pelalawan

\begin{tabular}{clc}
\hline NO & \multicolumn{1}{c}{ RENTANG USIA } & PERSENTASE \\
\hline 1 & $20-30$ tahun & $\mathbf{1 0 \%}$ \\
2 & $31-40$ tahun & $\mathbf{1 5 \%}$ \\
3 & $41-50$ tahun & $\mathbf{4 0 \%}$ \\
4 & $51-$ ke atas & $\mathbf{3 0 \%}$ \\
\hline
\end{tabular}

Tabel di atas menggambarkan bahwa persentase tingkat usia pedagang perempuan yang ada di Kabupaten Pelalawan menunjukkan angka persentase sedikit lebih tinggi pada rentang usia 41-50 tahun dibandingkan pada rentang usia 51 ke atas. Kelihatannya antara kedua rentang usia pedangan perempuan ini hampir seimbang, artinya pedagang perempuan di pasar-pasar sekitar wilayah Pelalawan ini rat-rata berusia di atas 40 tahun.

Selanjutnya aktivitas dagang di pasar ini sudah mulai dilakukan sejak pukul 06.00 WIB sampai 18.00 WIB. Sedangkan beliau sendiri sudah mulai menggelar dagangannya pukul 06.00 WIB. Pekerjaan ini dilakukan 
untuk memenuhi kebutuhan hidup. Rata-rata pedagang-pedagang di pasar ini berdagang dengan alasan untuk kebutuhan ekonomi dalam rangka pemenuhan kebutuhan rumah tangga.

Mengenai jenis barang yang didagangkan, RK menjelaskan bahwa dia sendiri sudah kurang lebih 10 tahun sebagai penjual ikan patin dan beberapa jenis ikan lainnya. Beliau juga menambahkan bahwa umumnya barang yang dijual di pasar ini juga bervariasi, mulai dari ikan, sayur mayur, sembako, pecah belah hingga ke pakaian. untuk pasar tradisonal pada umumnya mereka menjual sayur mayur dan sebagainya. Sementara untuk jenis barangbarang elektronik dan sejenisnya jarang dijual di pasar ini (pekan/mingguan). Pada umumnya kita bisa membeli di toko-toko besar yang ada di sepanjang jalan kota. Sedangkan untuk membeli pakaian, sepatu dan sejenisnya, biasanya pembeli lebih suka dan senang berbelanja di pasar kaget yang dibuka pada malam hari di sepanjang jalan kota tesebut.

Selain itu jika ditinjau dari sisi religiusitas, para pedagang sebelum menjalankan aktivitas berdagangnya, mereka terlebih dahulu melaksanakan kegiatan rutinitas keagamaan, seperti menjalankan ibadah shalat subuh. Hal ini sesuai dengan informasi dari salah seorang responden yang menyatakan bahwa pada umumnya mereka sudah melaksanakan shalat subuh di rumah sebelum berangkat ke pasar. Sedangkan pelaksanaan shalat Zuhur, hampir keseluruhan dari pedagang tersebut mengupayakan pulang ke rumah, karena rumah mereka tidak begitu jauh dari pasar. Hal ini mereka lakukan agar bisa melakukan pekerjaan rumah seperti memasak untuk makan siang. Setelah shalat Zuhur mereka kembali ke pasar untuk kembali beraktivitas berdagang hingga masuknya waktu Ashar. Oleh karena itulah jika kita amati pada jamjam siang waktu Zuhur tiba, pasar kelihatan mulai sepi.

Selanjutnya dalam hal melayani pembeli dan pelanggan, para pedagang perempuan cukup mampu mengakrabkan diri dengan pembeli dimulai dengan cara menyapa dan menawarkan dagangannya sehingga tawar-menawar barang berlangsung dengan akrab, dengan demikian hargapun bisa disepakati. Sedangkan pada jam-jam sibuknya aktivitas pasar, terkadang tidak semua pembeli terlayani dengan sepenuhnya, walaupun demikian pembeli memahami kondisi tersebut hingga melayani diri sendiri dengan cara memilih dan menimbang barang sendiri,

Mengenai penetapan harga pokok barang, para penjual sudah menetapkan sesuai harga standar. Terkadang pedagang bermurah hati dengan cara memberikan bonus tambahan barang atau kelebihan timbangan kepada pembeli agar pembeli merasa senang dan untuk selanjutnya bisa menjadi pelanggannya. 
d. Pedagang Perempuan Di Kota Dumai

Dari hasil wawancara yang dilakukan di pasar kota Dumai, yakni pasar Dock, pada tanggal 1 Oktober 2010 terhadap salah seorang responden yang berinisial UP berusia 43 tahun yang berasal dari Suku Minang mengatakan bahwa pasar ini sangat strategis, karena berada di pusat kota dan bersebelahan dengan pelabuhan besar Dumai dan merupakan pasar yang cukup luas jika dilihat dari ukurannya. Jumlah pedagang yang ada diperkirakan sekitar 500-600 orang, dan mayoritas pedagang tersebut adalah perempuan. Responden berjualan lebih kurang 8 tahun dengan sistem berjualan berkeliling atau menjajakan dagangannya. Beliau juga menambahkan bahwa di pasar tersebut, masih banyak para pedagang perempuan khususnya, berdagang dengan berpindah-pindah. Hal ini disebabkan karena mereka belum memiliki kios atau lapak secara permanen.

TABEL 4

Persentase Rentang Usia Pedagang Perempuan Kota Dumai

\begin{tabular}{ccc}
\hline NO & \multicolumn{1}{c}{ RENTANG USIA } & PERSENTASE \\
\hline 1 & $20-30$ tahun & $\mathbf{1 5 \%}$ \\
2 & $31-40$ tahun & $\mathbf{3 0} \%$ \\
3 & $41-50$ tahun & $\mathbf{4 5 \%}$ \\
4 & $51-$ ke atas & $\mathbf{1 0 \%}$ \\
\hline
\end{tabular}

Tabel di atas menggambarkan bahwa persentase tingkat usia pedagang perempuan yang ada di kota Dumai menunjukkan banyak pada rentang usia 50 tahun ke atas. Dapat disimpulkan bahwa perempuan yang berdagang di wilayah Dumai rata-rata berusia lanjut, walaupun masih tidak menutup kemungkinan juga terdapat pada rentang usia muda dengan persentase yang kecil.

Religiusitas pedagang perempuan muncul pada saat mereka menjalankan aktivitas dagang, seperti penjual selalu memperhatikan beberapa hal, misalnya dalam hal melaksanakan kegiatan rutinitas keagamaan (shalat), keramahan melayani pelanggan, menimbang barang, dan menetapkan harga. Responden menjelaskan bahwa aktivitas berdagang tidak mengganggu pelaksanaan ibadah, seperti dalam menjalankan ibadah shalat. Artinya shalat tetap dilaksanakan sesuai waktunya meskipun terkadang agak sedikit terlambat, terutama waktu Shalat Zuhur. Keterlambatan mereka dalam menjalankan aktivitas ini disebabkan karena bertepatan pada saat tersebut situasi pasar sangat ramai dikunjungi pembeli. Apalagi kalau sudah ada kapal masuk dan datang dari pulau-pulau lain, maka dapat dipastikan banyak barang 
yang masuk begitu juga dengan penumpang kapal yang turut turun untuk berbelanja.

Berkaitan dengan pelayanan pembeli, misalnya pada saat jam sibuknya aktivitas pasar, terkadang tidak semua pembeli terlayani dengan maksimal. Salah satu gambaran pasar yang sering diamati misalnya, situasi pasar tidak ubahnya seperti di swalayan yang melayani diri sendiri dengan cara memilih dan menimbang barang sendiri, kemudian tinggal menghitung dan membayarnya, hal ini disebabkan karena riuh dan ramainya pembeli. Sangat berbeda, jika situasi pasar lagi normal dimana penjual dapat melayani pembeli dengan maksimal, kadang-kadang tidak heran diselingi oleh tawa dan canda dalam rangka mengakrabkan diri dengan pembeli. Upaya ini dijadikan sebagai salah satu strategi dalam menarik pembeli untuk menjadi pelanggan tetap mereka.

Di pasar Dock ini, jika situasi pasar lagi sepi, biasanya pembeli memilih barang sesuai kesukaan masing-masing, kemudian penjual memberikan kesempatan untuk menakar sendiri, setelah itu baru penjual menghitung nilai barang yang ditimbang pembeli tersebut dengan harga yang sesuai dengan harga pasaran. Sebaliknya, jika pasar dalam keadaan ramai, biasanya pembeli memilih barang sendiri, setelah itu diserahkan kepada penjual untuk ditimbang sesuai dengan keinginan pembeli, kemudian penjual menghitung dan menetapkan harga sesuai dengan nilai barang tersebut. Penetapan harga barang disesuai dengan harga pasaran dengan tidak mengambil untung terlalu besar, apalagi untuk jenis barang dagangan seperti sayur-sayuran. Bagi pedagang perempuan muslim, proses penimbangang dan penetapkan harga nampaknya disesuaikan dengan ketentuan-ketentuan yang mereka pahami.

Salah seorang Satpam di pasar tersebut, menjelaskan bahwa di pasar Dock ini kebanyakan pedagang adalah ibu-ibu yang berusia 40 tahun ke atas dan mereka umumnya menjual jenis dagangan sayursayuran dan lauk-pauk. Selain itu mengenai ibadah, pada umumnya ibu-ibu tersebut sebelum waktu Zhuhur tiba mereka sudah pulang. Hal ini disebabkan rata-rata dagangan jenis ini sebelum siang sudah habis dibeli orang-orang yang berjualan di rumah, meskipun masih terdapat sebagian kecil yang masih berjualan di pasar pada sore harinya.

\section{Analisis Data}

Propinsi Riau terdiri dari beberapa kabupaten kota, dan yang dijadikan sampel hanya 4 kabupaten kota dengan perincian jumlah penduduk berikut ini :

TABEL 5

Jumlah Penduduk Riau Pada Empat Kabupaten/Kota

\begin{tabular}{clc}
\hline NO & WILAYAH RIAU & JUMLAH PENDUDUK \\
\hline 1 & Kota Pekanbaru & 717.618 Jiwa \\
2 & Kabupaten Kampar & 686.030 Jiwa \\
\hline
\end{tabular}




\begin{tabular}{lll}
\hline 3 & Kabupaten Pelalawan & 303.021 Jiwa \\
4 & Kota Dumai & 254.337 Jiwa \\
\hline
\end{tabular}

Berdasarkan penyebaran agama, maka Riau. Hal ini dapat dilihat berdasarkan dapat disimpulkan bahwa agama Islam persentase di bawah ini : merupakan agama yang dominan di wilayah

TABEL 6

Persentase Penyebaran Agama Masyarakat Propinsi Riau

\begin{tabular}{ccc}
\hline NO & AGAMA & PERSENTASE \\
\hline 1 & Islam & $87,04 \%$ \\
2 & Kristen & $6.13 \%$ \\
3 & Katolik & $3.66 \%$ \\
4 & Hindu & $1.85 \%$ \\
5 & Budha & $1.85 \%$. \\
\hline
\end{tabular}

Dari tabel di atas, dapat disimpulkan bahwa persentase pemeluk agama Islam lebih banyak dibandingkan dengan agamaagama lain dengan persentase rata-ratanya sektar $87,04 \%$. Hal ini dipengaruhi oleh suku yaitu Suku Melayu dan Minang yang identik dengan agama Islam.

Ditinjau dari segi perekonomian, terutama dalam pemenuhan kebutuhan hidup, masyarakat Provinsi Riau ada yang beraktivitas sebagai nelayan, pedagang, petani, buruh, maupun di pemerintahan. Dari beberapa aktivitas tersebut ternyata aktivitas berdagang yang lebih banyak dilakukan. Hal ini dipengaruhi oleh kota yang sedang berkembang dan strategis dalam perdagangan baik dalam maupun luar negeri. Aktivitas berdagang di pasar ini di dominasi oleh pedagang perempuan dengan rentangan usia berikut ini:

TABEL 7

Persentase Rentang Usia Pedagang Perempuan di Propinsi Riau

\begin{tabular}{ccc}
\hline NO & RENTANG USIA & PERSENTASE \\
\hline 1 & $20-30$ tahun & $\mathbf{1 2 . 5 \%}$ \\
2 & $31-40$ tahun & $\mathbf{2 1 . 2 5 \%}$ \\
3 & $41-50$ tahun & $\mathbf{4 3 . 7 5 \%}$ \\
4 & $51-$ ke atas & $\mathbf{2 1 , 2 5 \%}$ \\
\hline
\end{tabular}

Secara umum, penelitian ini merupakan pekerjaan yang mudah menggambarkan bahwa usia pedagang dilakukan, tidak terlalu banyak resiko, tidak perempuan berada pada tingkat usia 41 - 50 tahun sekitar $43.75 \%$. Hal ini disebabkan karena berdagang bagi perempuan harus melalui administrasi yang rumit, yang penting adalah niat yang kuat dan bersungguh-sungguh dalam 
berusaha/berdagang. Jenis barang yang didagangkan juga beragam, mulai dari sayur mayur, lauk pauk, beras, dll. Sebagian pedagang sudah memiliki kios/lapak, tapi sebagian yang lain belum memiliki kios/lapak.

Selanjutnya dalam hal menjalankan ibadah keagamaan, pedagang perempuan yang beragama Islam ditemukan sebagian dari mereka menjalankan ibadah Shalat (terutama Shalat Zuhur dan Ashar) tepat di awal waktu, sebagian yang lain ada yang menunda shalat hingga ada yang menggantikan menjaga kios, ada juga yang tidak melaksanakan shalat dengan alasan tertentu. Pelaksanaan Shalat mereka laksanakan di mesjid, mushalla dan kios/lapak tempat berjualan. Sedangkan untuk shalat selain Zuhur dan Ashar, mereka laksanakan di rumah.

Sementara itu dalam aktivitas jual-beli, terutama pada aspek pelayanan pembeli, mereka melayani sesuai dengan syariat agama, misalnya dalam hal keramahan melayani pelanggan, tergambar dari cara melayani pembeli dengan sapaan yang baik, senyum yang tulus dan diselingi dengan gurauan yang menarik sehingga terjalin rasa kekeluargaan.

Kemudian, dalam aspek penimbangan, para pedagang berusaha melakukan timbangan di hadapan pembeli secara transparan, Hal ini dilakukan agar tidak terjadi kecurangan dan juga menimbulkan rasa puas terhadap pembeli. Hal ini juga dipengaruhi oleh keyakinan mereka terhadap aturan-aturan agama. Tapi di sisi lain masih ada beberapa pedagang perempuan yang tidak perhatian dengan alat timbangannya, apakah masih berfungsi dengan baik atau tidak (entah disengaja entah tidak), sehingga merugikan pembeli yang mendapatkan barang tidak sesuai dengan takarannya.

Dalam hal penetapan harga, mereka menyesuaikan dengan kondisi harga di pasaran, dengan tidak mengambil keuntungan yang terlalu tinggi. Masalah harga bagi mereka merupakan faktor penentu dari nilai jual-beli barang setiap harinya, oleh sebab itu, mereka lebih realistis terhadap harga-harga di pasaran. Hal ini mereka lakukan dengan prinsip supaya jualan mereka bisa habis dan dapat ditambah dan bertukar kembali setiap harinya.

Untuk pedagang perempuan yang beragama Kristen, dalam pelaksanaan ibadah khususnya pada hari Minggu pagi, sebagian pergi beribadah ke gereja dan sebagian yang lain tidak pergi dengan alasan-alasan tertentu, diantaranya mereka lebih memilih berdagang karena pasar pada hari minggu lebih ramai dikunjungi para pembeli.

Dilihat dari aspek pelayanan pelanggan, mereka melayani dengan baik dan sedikit tegas, hal ini disebabkan karena kultur budaya mereka (mayoritas dari Sumatera Utara) dalam berkomunikasi cenderung dengan logat yang khas. Sedangkan pada aspek penimbangan, para pedagang juga melakukan timbangan di 
hadapan pembeli secara transparan, seperti halnya yang dilakukan oleh pedagang perempuan yang beragama Islam. Masalah standarisasi alat timbang juga patut dipertanyakan, sebagian menimbang dengan alat timbang yang baik dan sebagian yang lain menggunakan alat timbang yang tidak baik (misal, alat timbang yang sudah tidak patut digunakan maupun alat timbang yang sudah di rekayasa oleh si penjual).

Untuk yang beragama Hindu, Budha, dan Konghucu yang mayoritas dianut oleh Etnis Tionghoa, sebelum aktivitas dagang dilakukan mayoritas mereka terlebih dahulu melakukan persembahyangan sesuai dengan tata cara peribadatan agama mereka.

Dalam hal penimbangan barang Etnis Tionghoa bersikap jujur, kemudian dalam penetapan harga jarang terjadi tawarmenawar, karena mereka sudah menetapkan harga yang pas sesuai harga pasaran. Prinsip pedagang Tionghoa, mereka tidak perlu mengambil untung sebesar-besarnya yang penting perputaran barang berjalan dengan cepat.

Sedangkan yang menjadi faktor keterlibatan kaum perempuan dalam aktivitas berdagang dapat terlihat secara internal dan eksternal. Adapun secara internal, faktor yang menyebabkan mereka terlibat dalam aktivitas berdagang adalah sebagai berikut:

1. Adanya dorongan untuk pemenuhan kebutuhan hidup yang dirasa tidak cukup hanya dari penghasilan kepala keluarga (suami) saja.

2. Ketebatasan pendidikan dan keterampilan yang memadai secara formal, sehingga menyulitkan bagi mereka untuk dapat terlibat pada aktivitas selain berdagang.

3. Adanya perasaan dan pemahaman bahwa aktivitas berdagang dirasakan sebagai pekerjaan yang tidak begitu besar tekanannya, jika dibandingkan dengan pekerjaaan pada sektor formal.

4. Adanya anggapan bahwa berdagang merupakan pekerjaan yang tidak berisiko terlalu tinggi. Selain itu juga berdagang dirasakan sebagai pekerjaan mudah dilakukan tanpa membutuhkan pendidikan formal.

Sedangkan secara eksternal, faktor yang menyebabkan pedagang perempuan terlibat dalam aktivitas berdagang adalah sebagai berikut;

1. Paradigma industrialisasi dalam pembangunan yang memicu pertumbuhan penduduk dan angka kemiskinan di desa tinggi dan pendapatan di kota yang lebih tinggi dari pada di desa, sehingga hal ini menyebabkan masyarakat lebih memilih berdagang sebagai pekerjaan yang mudah.

2. Kondisi alam yang tandus, krisis air, dan berbukit-bukit menyebabkan berdagang adalah pilihan yang mudah untuk 
dilakukan sebagai upaya untuk menambah pendapatan.

\section{KESIMPULAN}

Aktivitas berdagang di pasar tradisional Propinsi Riau banyak dilakukan oleh kaum perempuan, dan didominasi oleh perempuan dengan rentang usia 41-50 tahun. Mayoritas pedagang perempuan di wilayah Riau beragama Islam, dan hampir sebagian besar bersuku Melayu dan Minang. Religiusitas sebagian pedagang perempuan di pasar tradisional dapat dikategorikan baik (taat) dan masih ada sebagian yang dikategorikan kurang baik (kurang taat), ini dapat dilihat pada pelaksanaan shalat Zuhur dan Ashar tepat waktu atau tidak bagi yang beragama Islam, pergi beribadah ke gereja atau tidak bagi yang beragama Kristen, begitu juga dengan agama lain apakah mereka melaksanakan ibadahnya atau tidak saat mereka berdagang, ramah atau tidak dalam melayani pembeli, jujur atau tidak dalam menimbang barang, dll. Keterlibatan kaum perempuan dalam berdagang di pasar tradisional dipengaruhi oleh faktor internal dan eksternal.

\section{SARAN}

a. Kepada pedagang perempuan dalam setiap aktivitas, khususnya dalam hal berniaga atau jual beli hendaklah tetap berpedoman pada prinsip atau etika dagang yang sesuai dengan ketentuan dan keyakinan agama masing-masing. b. Mengingat berdagang merupakan salah satu usaha yang dimuliakan Tuhan Yang Maha Esa dalam memenuhi kebutuhan ekonomi, maka sepatutnyalah aktivitas ini dilakukan dengan tujuan yang baik serta mengharapkan ridha-Nya.

c. Selanjutnya, penelitian ini diharapkan agar dapat dilanjutkan dan dikembangkan pada tingkat yang lebih tinggi.

\section{Endnotes:}

1 Arrie Stephanie, Strategi Nafkah Pedagang Perempuan di sektor informal perkotaan (studi kasus pedagang perempuan di pasar Anyar kota Bogor propinsi Jawa Barat). IPB. 2008. h. 34

2 Ibid. h. 36

3 Astuti dkk. Prospek Sektor Informal Perdagangan (Studi kasus perempuan pedagang Pasar Johar Semarang). Lembaga Penelitian Universitas Diponegoro. 2004. h. 58

4 Ensiklopedi Islam. 2001. h. 186

5 Ed. Siti Hariti Sastriani, Woman in Public Sector, (Yogyakarta: Pusat Studi Wanita Universitas Gajah Mada, 2005), h. 255

6 Sanapiah Faisal, Format-format Penelitian Sosial, (Jakarta: PT. Raja Grafindo Persada, 2010), h. 70

7 R. Bogdan dan Taylor, Introduction Qualitative Research Methods, (New York, 1975), h. 4

\section{DAFTAR PUSTAKA}

Al-Qur'an terjemah, Jakarta : Depag.

Arifin, Bey Al-Muhdhor . Ali , Yunus Ustadz dan Dra. Ummu Maslamah Rayes. 
1993, Tarjamah Sunan An-Nasa'iy, jilid III, Semarang. CV. Asy-Syifa'.

Arifin, Bey Al-Muhdhor . Ali , Yunus Ustadz dan Dra. Ummu Maslamah Rayes. 1993, Tarjamah Sunan An-Nasa'iy, jilid IV, Semarang. CV. Asy-Syifa'.

Arrie Stephanie, 2008, Strategi Nafkah Pedagang Perempuan di sektor informal perkotaan (studi kasus pedagang perempuan dipasar Anyar kota Bogor Provinsi Jawa Barat), Bogor: IPB

Astuti, dkk.,, 2004, Prospek Sektor Informal Perdagangan (Studi kasus perempuan pedagang Pasar Johar Semarang), Semarang: Lembaga Penelitian Universitas Diponegoro

R. Bogdan dan S.J. Tylor, 1975, Introduction Qualitative Research Methods, New York

Ensiklopedi Islam. 2001

Sanapiah Faisal, 2010. Format-format Penelitian Sosial. PT. Raja Grafindo Persada. Jakarta.

Profil Pariwisata Riau, Pekanbaru: Dinas Kebudayaan, Kesenian dan Pariwisata Provinsi Riau

Riau dalam Angka (Riau in Figures) 2010, 2010, Pekanbaru: BPS Provinsi Riau

Riau Province (Regional Profile E Investment Opportunities), 2006, Pekanbaru: Promotion and Investment Board Riau Province

Ed. Siti Hariti Sastriani, 2005, Woman in Public Sector, Yogyakarta: Pusat Studi Wanita Universitas Gajah Mada

DR. Sufian Hamim, M.Si, 2003, Sistem Perencanaan Strategis dalam Pembangunan, Pekanbaru: UIR Press

Zuhri, Moh. Dipl. Tafl dkk, 1992. Terjemahan Sunan At-Tirmidzi. Jilid II. Semarang. CV. Asy-Syifa'. 